\title{
Localized expression of the atrial natriuretic factor gene during cardiac embryogenesis
}

\author{
Rolf Zeller, ${ }^{1,2}$ Kenneth D. Bloch, ${ }^{1}$ Betsey S. Williams, ${ }^{3}$ Robert J. Arceci, ${ }^{4}$ and Christine E. Seidman ${ }^{1}$ \\ ${ }^{1}$ Department of Genetics, Harvard Medical School, ${ }^{2}$ Howard Hughes Medical Institute; ${ }^{3}$ Department of Anatomy and Cellular \\ Biology, Harvard Medical School; ${ }^{4}$ Department of Pediatric Hematology-Oncology, Dana-Farber Cancer Institute, \\ Boston, Massachusetts 02115 USA
}

\begin{abstract}
Expression of the gene encoding atrial natriuretic factor (ANF) during mouse cardiac embryogenesis was studied using in situ hybridization to histologic sections. ANF mRNA was first detected in a subpopulation of myocardial cells at day 8 of embryogenesis. During day 9, abundant hybridization of the ANF probe to the atrium and the primitive ventricle was found. At day 14, strong labeling of cells in both atria and the trabeculated regions of the left ventricle was seen, whereas fewer cells in the right ventricle expressed the ANF gene. The developmental regulation of ANF gene expression in atrial and ventricular cells suggests an important role for this peptide hormone in the embryo. Localized expression of the ANF gene provides a marker for discerning subpopulations of cardiac cells during embryogenesis. Identification of embryonic ventricular ANF mRNA transcripts may have implications with respect to pathologic reexpression of the ANF gene in adult ventricles.
\end{abstract}

[Key Words: ANF gene; cardiac embryogenesis; in situ hybridization]

Received May 19, 1987; revised version accepted June 16, 1987.

Mammalian cardiac tissues secrete atrial natriuretic factor (ANF), a peptide hormone with natriuretic and vasoactive properties (deBold et al. 1982; Currie et al. 1984). In adults, ANF is synthesized predominantly in the atria and appears to be important for intravascular volume and pressure homeostasis (Needleman et al. 1985; Cantin and Genest 1986). The ANF gene is expressed at low levels in adult ventricles (Gardner et al. 1986; Nemer et al. 1986), but higher levels are induced by ventricular hypertrophy (Lattion et al. 1986; Takayanagi et al. 1987; Wiegand et al. 1987). Abundant ANF mRNA and peptide have been found in the ventricles of neonatal rats (Bloch et al. 1986). After birth these levels decline rapidly. Ventricular ANF peptides have also been identified by Thompson et al. (1986) in fetal ventricles, using immunohistochemical techniques.

To determine the onset of transcription and spatial expression of the ANF gene during embryogenesis, we studied the distribution of ANF mRNA in mouse embryos using in situ hybridization. We report that the ANF gene is expressed as early as day 8 of gestation. A detailed analysis of successive embryonic stages showed localized ventricular ANF gene transcription in addition to diffuse atrial expression. This study identifies discrete cardiac regions potentially involved in synthesis of this peptide during embryogenesis. Expression of the ANF gene by these regions may either be due to the spatial distribution of a cell population committed to gene expression or to local gene induction in response to unknown stimuli. The described temporal and morphogenetic pattern of ANF gene transcription predicts an important role for this cardiac hormone during embryogenesis.

Results

Expression of the ANF gene during embryogenesis

Mouse embryos of days 7, 8, 9, and 14 and 1-day-old neonatal hearts were fixed and processed for in situ hybridization (see Materials and methods). An ANF antisense RNA probe (Cox et al. 1984), derived from a 986-bp genomic fragment of the murine ANF gene (Fig. 1b; Seidman et al. 1984), was radiolabeled with [ ${ }^{35}$ S]UTP. This probe was used to localize ANF mRNA transcripts in embryonic tissues.

The ANF probe was hybridized to histologic sections of day-7 embryos. No ANF mRNA was detected by either in situ hybridization or an RNase protection assay using total RNA isolated from day-7 embryos (data not shown).

Day-8 mouse embryos contain a contracting tubular heart composed of two epithelial layers, the outer myo- 
Zeller et al.
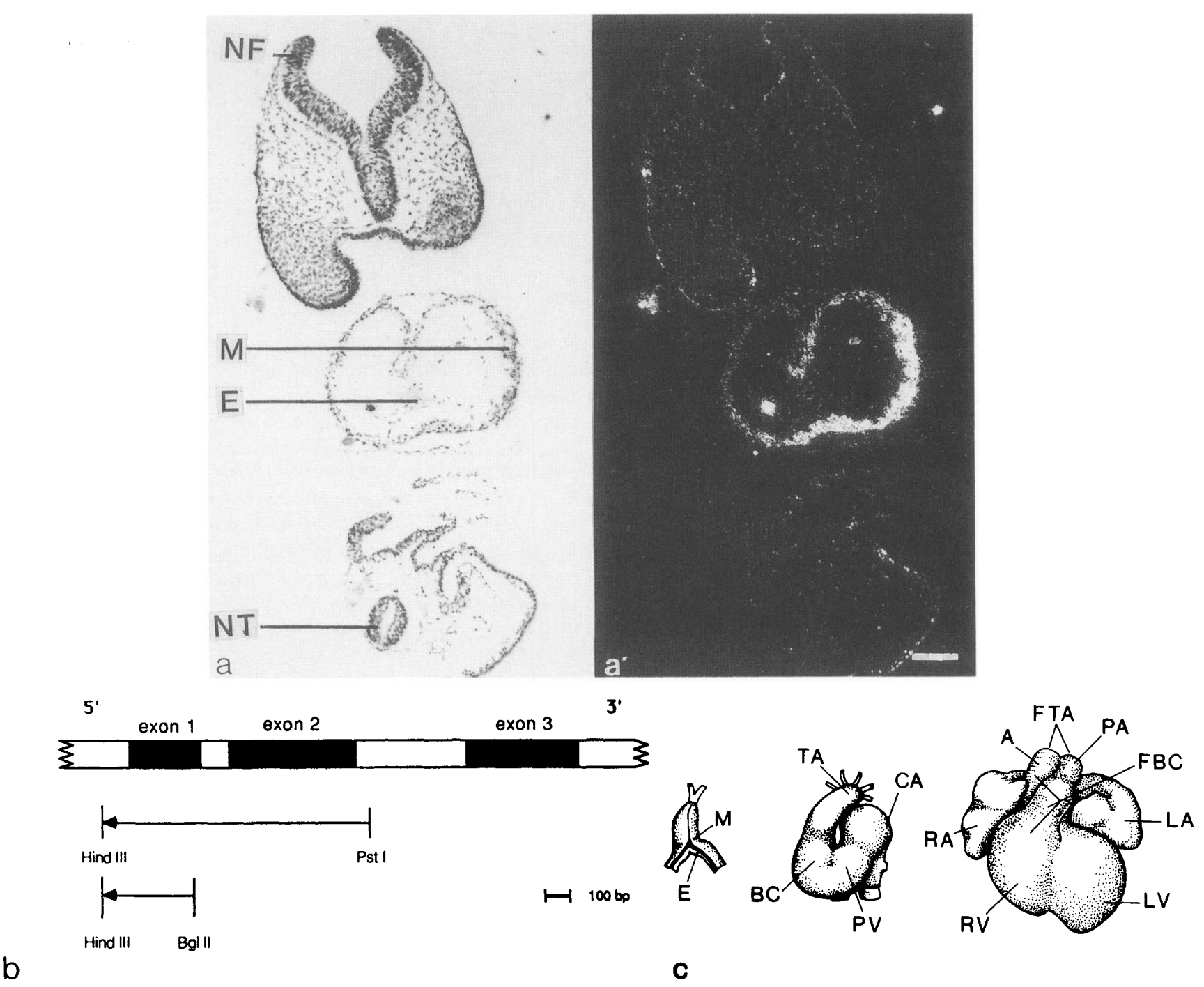

b

Figure 1. ANF gene expression in the heart of a day-8 mouse embryo. (a) Transillumination photograph of a section hybridized to a ${ }^{35}$ S]UTP-labeled ANF RNA probe (see $b$ ) and counterstained with Wright's Stain (E) Endocardium; (M) myoepicardium; (NF) neural fold; (NT) neural tube. $\left(a^{\prime}\right)$ Dark-field illumination photograph of section shown in $a$ to reveal specific hybridization. Bar, $100 \mu m$. $(b)$ Schematic of the mouse ANF gene (Seidman et al. 1984). A single-stranded antisense [ ${ }^{35}$ S]UTP-labeled RNA probe (long arrow) derived from the 986-bp HindIII-Pst fragment containing exons 1 and 2 (subcloned into pGEM 4 vector) was used for in situ hybridization (see Materials and methods). The complementary sense probe was used to reveal nonspecific hybridization (Fig. 4b). For RNase protection assays (Rebagliati et al. 1985) an antisense RNA probe derived from a 340-bp HindIII-BglII fragment was used (short arrow). (c) Schematic of mammalian heart development. The immature embryonic heart (left) consists of an internal endocardial tube (E) and an external myoepicardial tube (M). Extensive differential growth and rotation results in a heart loop (middle). The common atria (CA), primitive ventricle (PV), bulbus cordis $(B C)$, and truncus arteriosus (TA) are identified. Further development yields the more mature fetal heart (right). (RA) Right atrium; (LA) left atrium; (RV) right ventricle; (LV) left ventricle; (FBC) former bulbus cordis; (FTA) former truncus arteriosus; (A) aorta; (PA) pulmonary artery. (Redrawn from DeHaan 1965 and Arey 1974.)

epicardium and inner endocardium (Fig. 1c, left; Snell and Stevens 1968; Rugh 1968). Of five day-8 embryos examined, specific ANF hybridization was observed in two developing hearts (Fig. 1a, $a^{\prime}$ ). Expression was localized to a subpopulation of myocardial cells. No hybridization signal was detected in cells of the endocardial layer of the primitive heart. To confirm expression of the ANF gene at this early developmental stage, total RNA isolated from pooled day- 8 embryos was hybridized to an ANF genomic probe derived from 5 '-flanking sequences and part of exon 1 (Fig. $1 \mathrm{~b}$ ) in an RNase protection assay (Rebagliati et al. 1985). A small amount of accurately initiated ANF mRNA was detected (data not shown|, consistent with the day-8 in situ hybridization results. Since embryos collected on a particular day of gestation vary in their degree of development (Allen and MacDowell 1940; see also Materials and methods), we suggest that ANF mRNA may be present only in the more advanced embryos. We conclude that ANF gene transcription starts as early as day- 8 of gestation. 
The embryonic day-9 heart loop forms as a result of rotation of the immature cardiac tube and extensive differential growth (Fig. 1c, middle; Rugh 1968; Snell and Stevens 1968). The primitive atria are continuous with the sinus venosus and the bulboventricular tube. The primitive ventricle is identified as that region of the bulboventricular tube (contiguous with the atria) that comes to lie in the left of the pericardial cavity and develops into the left ventricle (LV) (Fig. 2a, b). Continuous with the primitive ventricle is that region of the bulboventricular tube called the bulbus cordis. The right ventricle $(\mathrm{RV})$ is derived from a portion of the bulbus cordis that lies in the right side of the pericardial cavity. The distal portion of the bulbus cordis, which overlies the atria, becomes the truncus arteriosus.

Analysis of four day-9 embryos by in situ hybridization revealed prominent labeling in the atria and primitive ventricle (Fig. 2a, b). In contrast, only faint labeling was apparent in the bulbus cordis (Fig. 2b, dark field). No hybridization was seen in the truncus arteriosus (Fig. 2a), the sinus venosus (not illustrated), or cells of the bulbus cordis nearest the primitive ventricle (Fig. 2b).

By day-14, septation of the heart is complete, internal trabeculae are present in both the RV and LV, and the fetal circulatory pattern is established (Fig. 1c, right). Hybridization of the ANF probe was evident in both atria (Fig. 3). Trabeculated regions within the LV expressed ANF transcripts in amounts comparable to those in atrial tissues. In contrast, the RV contains markedly fewer cells expressing the ANF gene. Serial histologic sections of day-14 fetal hearts consistently showed this differential expression pattern. No signal was found in the RV and LV outflow tracts, the arch of the aorta (all derived from the distal bulbus cordis), the cardiac valves (derived from endocardial cushions), or the interventricular septum.

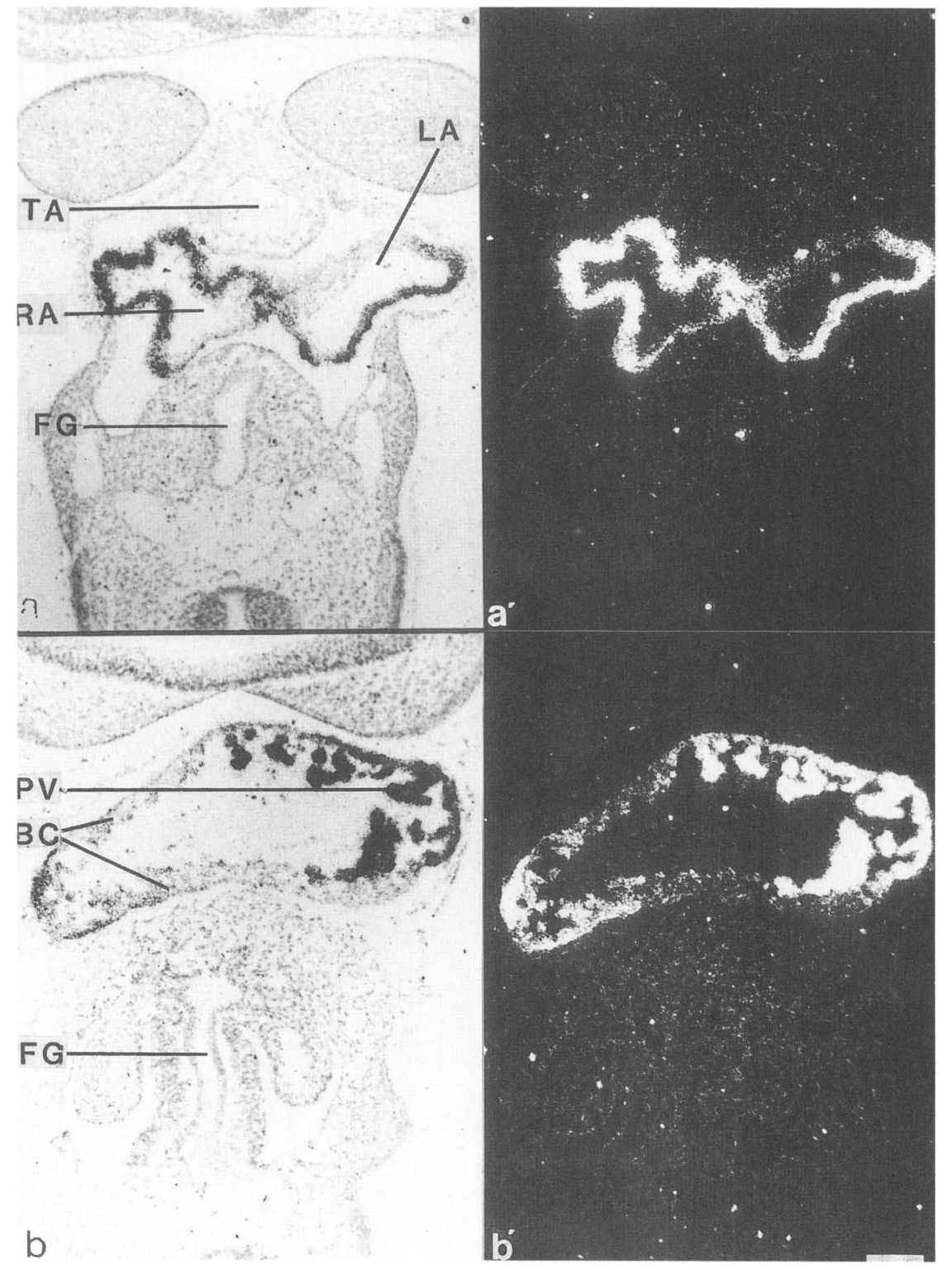

Figure 2. Expression pattern of the ANF gene in a day-9 mouse embryo. (a) Transillumination photograph of a transverse section showing atrial hybridization; $\left(a^{\prime}\right)$ dark-field illumination photograph of section shown in $(a) ;(b)$ a more caudal transverse section through the bulboventricular region showing localized hybridization in the primitive ventricle; $\left(b^{\prime}\right)$ dark-field illumination photograph of section shown in $b$. Anatomical nomenclature is the same as in Fig. 1. (FG) Foregut. The right ventricle is derived from the portion of the bulbus cordis that lies in the right side of the pericardial cavity. Bar, $100 \mu \mathrm{m}$. 
Zeller et al.

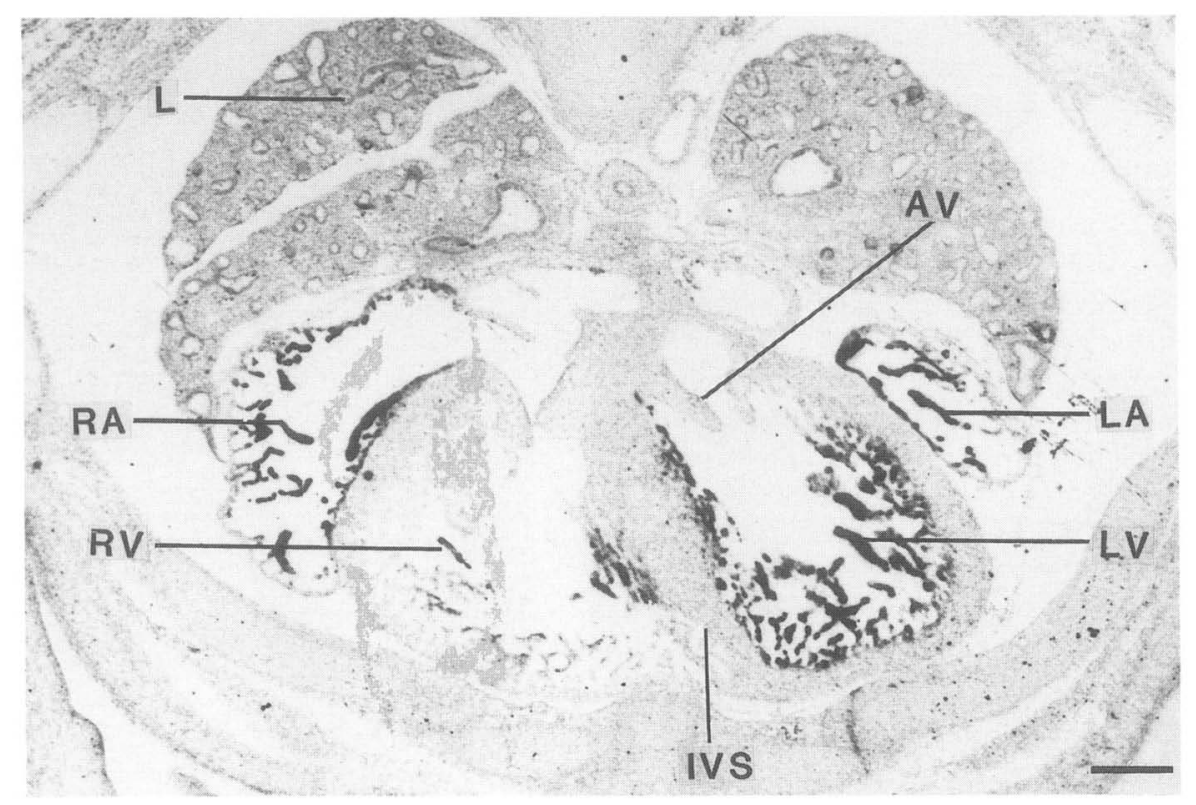

Figure 3. Transillumination photograph of a typical transverse section through a day-14 mouse embryo showing localized ANF gene expression in the fetal heart. Anatomical nomenclature is the same as in previous figures. (AV) Aortic valve; (IVS) interventricular septum; (L) lungs. Lungs show dark counterstain with Wright's Stain. Bar, $200 \mu \mathrm{m}$.

\section{Expression of the ANF gene in the 1-day-old neonatal heart}

Hybridization of the antisense ANF probe (Fig. $1 \mathrm{~b}$ ) to isolated 1-day-old neonatal hearts (Fig. 4a) showed dramatic labeling of both atria. Expression in the ventricles was mainly confined to trabeculated regions, in a pattern similar to that found in the septated day-14 fetal heart (Fig. 3), but at levels considerably lower than in the atria. This observation was confirmed by Northern blot analyses (data not shown). In contrast, previous studies in neonatal rats showed ventricular mRNA levels ap-
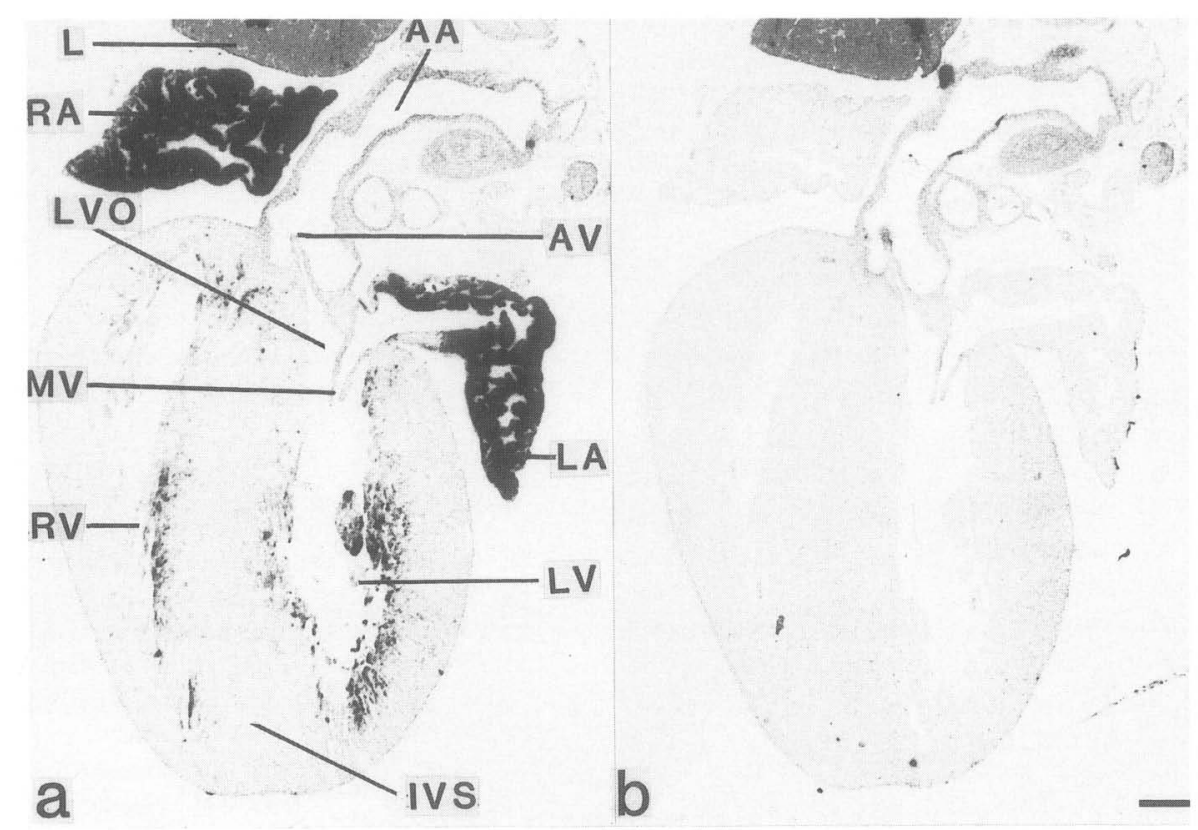

Figure 4. Localization of ANF transcripts in a 1-day-old neonatal mouse heart. $(a)$ Hybridization of a longitudinal section with the antisense ANF RNA probe (Fig. 1b) showed specific ANF gene expression. $(b)$ Hybridization of a contiguous section to the corresponding sense RNA probe showed little nonspecific hybridization. Lungs show dense counterstain with Wright's Stain in $a$ and $b$. Anatomical nomenclature is the same as in previous figures. (AA) Arch of the aorta; (LVO) left ventricular outflow tract; (MV) mitral valve. Bar, $200 \mu \mathrm{m}$. 
proximately equal to atrial levels (Bloch et al. 1986). These results indicate that the ratio of atrial to ventricular ANF mRNA levels in the neonate may vary between species.

Hybridization of a $\left.{ }^{35} \mathrm{~S}\right] \mathrm{UTP}$-labeled sense ANF RNA probe to a serial histologic section from a 1-day-old neonatal heart showed minimal signal (Fig. 4b). A similar series of control experiments using the sense probe was performed for all stages of embryonic development. Background hybridization was similar to that seen in Figure $4 b$.

\section{Discussion}

Is embryonic ANF gene expression controlled by cell fate?

This study establishes the onset of ANF gene expression in the developing heart at day- 8 of gestation. High levels of localized ANF gene expression during mouse cardiac embryogenesis are documented, suggesting a role for this peptide hormone in the developing embryo. Two models may be proposed to explain the observed temporal and spatial pattern of ANF gene expression.

One model proposes that only a subpopulation of primordial cardiac cells is committed to express the ANF gene. Differential growth and torsion of the heart tube segregates a population of ANF-expressing cells predominantly into the developing atria and LV. Nonexpressing cells are localized in the bulbus cordis (Fig. 2a, b). If cells expressing the ANF gene are derived from a common lineage, hybridization will provide a marker to follow their fate from day- 8 throughout embryogenesis (Figs. $1-3$ ). In support of this model, labeling in the primitive ventricle (subsequently the LV) was comparable to hybridization of the embryonically contiguous atria (Figs. 2 and 3). In contrast, fewer cells of the RV hybridized, suggesting that only few cells committed to ANF mRNA transcription were segregated into this chamber.

A second model postulates that ANF mRNA transcription can be initiated in all cardiac cells in response to appropriate stimuli. Differential hybridization in contiguous regions of the developing heart (e.g., Fig. 2b) would be due to gene expression regulated by localized 'stimuli. Signals that distinguish the ANF mRNA-producing primitive ventricle from the adjacent nonexpressing bulbus cordis (Fig. 2b) have not been identified. Potential stimuli for local ANF gene induction can be postulated for the more mature fetal heart. The fetal circulation selectively channels highly oxygenated placenta-derived blood across both atria (via the foramen ovale) to the LV, whereas the RV receives poorly oxygenated, fetal-derived blood (Born et al. 1954; Rudolph and Heymann 1974). Differential oxygenation or blood flow may account for regional regulation of ANF gene expression. Hence, the atria and LV may receive similar and greater stimuli for gene activation than the RV.

As the embryonic expression patterns of more cardiac genes are characterized, cells derived from a common progenitor may be identified, permitting discrimination between these models.
Does ventricular ANF gene expression in cardiac hypertrophy represent regression to an embryonic state?

In the adult, ventricular expression of ANF increases with ventricular hypertrophy (Lattion et al. 1986; Takayanagi et al. 1987; Wiegand et al. 1987), a pathologic state associated with cardiovascular volume and pressure overload (Braunwald 1984). Recruitment of ventricles for ANF production has been postulated as a means to increase circulating levels of a vasorelaxant natriuretic hormone (Lattion et al. 1986; Takayanagi et al. 1987; Wiegand et al. 1987). An alternative explanation for induction of ventricular ANF gene expression might be that hypertrophy results in a return to an embryonic state by ventricular cells. Reexpression of developmentally regulated genes by differentiated adult cells in response to pathology has been demonstrated in the globin gene family (DeSimone et al. 1978; Busslinger et al. 1983). Further, chronic pressure overload has been shown to induce embryonic myosin gene expression in the adult rat ventricle (Izumo et al. 1987). Ventricular hypertrophy might therefore cause a generalized induction of developmentally regulated genes. ANF gene induction may be a useful marker for identifying reexpression of embryonic genes by adult ventricular cells as well as for tracing cell lineage during cardiac embryogenesis.

\section{Materials and methods}

Mouse embryos

CD1 outbred mice were mated, and every morning females were checked for vaginal plug formation. Day- 0 of gestation is the day the vaginal plug was found $(9-10$ A.M). The embryos collected on each gestational day for analysis by in situ hybridization or RNase protection (Rebagliati et al. 1985) represent heterogeneous pools collected from many females.

\section{In situ hybridization method}

Embryos were fixed in freshly prepared $4 \%$ paraformaldehyde $\left(4^{\circ} \mathrm{C}\right)$ for $30 \mathrm{~min}$ (isolated day-7 and day-8 embryos) to overnight (day 9 and older). Embedding in Paraplast (Monoject Scientific) and sectioning followed standard protocols (Zeller et al. 1983). Deparaffinized sections were pretreated for subsequent hybridization as described (Hafen et al. 1983; Carrasco and Malacinski 1987), except that Pronase digestion was omitted. Sulfhydryl groups were irreversibly blocked by treating sections for $10 \mathrm{~min}$ at $45^{\circ} \mathrm{C}$ in $1 \times$ phosphate-buffered saline (PBS) containing 10 $\mathrm{mM}$ dithiothreitol (DTT), followed by incubation in $1 \times$ PBS containing $10 \mathrm{~mm} \mathrm{DTT}, 10 \mathrm{~mm}$ sodium iodoacetamide, and 10 $\mathrm{mM} \mathrm{N}$-ethylmaleimide $\left(45^{\circ} \mathrm{C}\right.$, in darkness $)$ for $30 \mathrm{~min}$. Two acetylation reactions (Hayashi et al. 1978) were done for 5 min each. Dehydrated slides were hybridized to single-stranded ${ }^{35} \mathrm{~S}$ ]UTP-RNA probes (Cox et al. 1984) for $4 \mathrm{hr}$ at $50^{\circ} \mathrm{C}$ in buffer containing $50 \%$ deionized formamide, $0.3 \mathrm{M} \mathrm{NaCl}, 10 \mathrm{mM}$ Tris$\mathrm{HCl}(\mathrm{pH} 8.0), 1 \mathrm{~mm}$ EDTA, $1 \times$ Denhardt's solution, 10\% PEG $6000,50 \mathrm{mM}$ DTT, $500 \mu \mathrm{g}^{\prime} \mathrm{ml}$ polyadenosine, and $500 \mu \mathrm{g} / \mathrm{ml}$ poly(A) ${ }^{-}$RNA. Probe concentration was $300 \mathrm{ng} / \mathrm{ml} \sim 2 \times 10^{5}$ $\mathrm{cpm} / \mu \mathrm{l})$. Two sequential washes in $50 \%$ formamide, $2 \times$ SSC $\left(0.3 \mathrm{M} \mathrm{NaCl}, 0.03 \mathrm{M}\right.$ sodium citrate), $10 \mathrm{~mm}$ DTT at $50^{\circ} \mathrm{C}$ for 15 min were followed by two washes in $50 \%$ formamide, $2 \times \mathrm{SSC}$, $10 \mathrm{mM} \mathrm{DTT}$, and $0.5 \%$ Triton $\mathrm{X}-100$ at $50^{\circ} \mathrm{C}$ for $15 \mathrm{~min}$. Formamide was removed by rinsing twice in $2 \times$ SSC, $10 \mathrm{mM}$ DTT 
$\left(50^{\circ} \mathrm{C}\right)$. Slides were RNase-digested in $2 \times \mathrm{SSC}, 10 \mathrm{mM}$ DTT containing $50 \mu \mathrm{g} / \mathrm{ml} \mathrm{RNase} \mathrm{A,} 1 \mathrm{U} / \mathrm{ml}$ RNase T2, and $200 \mathrm{U} / \mathrm{ml}$ RNase $\mathrm{T} 1$ at $37^{\circ} \mathrm{C}$ for $30 \mathrm{~min}$. Subsequently, the slides were washed four times in $2 \times \mathrm{SSC}, 10 \mathrm{mM}$ DTT $\left(50^{\circ} \mathrm{C}\right)$ for $30 \mathrm{~min}$ and dehydrated. Autoradiogrpahy used standard techniques (Hafen et al. 1983). All sections were counterstained using Wright's Stain. In situ hybridization was performed on at least two unrelated specimens for each developmental day reported.

\section{Acknowledgments}

We thank Drs. A Carrasco, M. Rogers, and C.N. Berger for helpful suggestions with the in situ hybridization technique, Dr. E. Hay for assistance in embryonic structure identification, R. Wallace for animal handling, and Drs. P. Leder and J.G. Seidman for their enthusiastic support and encouragement. This work was supported in part by National Institutes of Health (NIH) grants HL35642, HL19259, by an EMBO longterm fellowship (R.Z.), a Pfizer postdoctoral fellowship (K.D.B.), NIH training grant 5T23CA09172-11 (R.J.A.), and an A.H.A. Clinician-Scientist Award (C.E.S.).

\section{References}

Allen, E. and E.C. MacDowell. 1940. Variation in mouse embryos of 8 days gestation. Anat. Rec. 77: 165-171.

Arey, L.B. 1974. Developmental anatomy: A textbook and laboratory manual of embryology, pp. 375-394. W.B. Saunders, Philadelphia.

Bloch, K.D., J.G. Seidman, J.D. Naftilan, J.T. Fallon, and C.E. Seidman. 1986. Neonatal atria and ventricles secrete atrial natriuretic factor via tissue-specific secretory pathways. Cell 47: 695-702.

Braunwald, E. 1984. Pathophysiology of heart failure. In heart disease: A textbook of cardiovascular medicine (ed. E. Braunwald), pp. 447-466. W.B. Saunders, Philadelphia.

Born, G.V.R., G.S. Daves, J.C. Mott, and J.G. Widdicombe. 1954. Changes in the heart and lungs at birth. Cold Spring Harbor Symp. Quant. Biol. 19: 102-108.

Busslinger, M., J. Hurst, and R.A. Flavell. 1983. DNA methylation and the regulation of globin gene expression. Cell 34: 197-206.

Cantin, M. and J. Genest. 1986. The heart as an endocrine gland. Sci. Am. 254: 76-81.

Carrasco, A.E. and G.M. Malacinski. 1987. Localisation of Xenopus homeobox gene transcripts during embryogenesis and in the adult nervous system. Dev. Biol. 121: 69-81.

Cox, K.H., D.V. DeJean, L.M. Angerer, and R.C. Angerer. 1984. Detection of mRNA in sea urchin embryos by in situ hybridisation using asymmetric RNA probes. Dev. Biol. 101: 485-502.

Currie, M.G., D.M. Geller, B.R. Cole, N.R. Siegel, K.F. Fok, S.P. Adams, S.R. Eubanks, G.R. Galluppi, and P. Needleman, 1984. Purification and sequence analysis of bioactive atrial peptides (atriopeptins). Science 223: 67-69.

deBold, A.J. 1982. Atrial natriuretic factor of the rat heart: Studies on isolation and properties. Proc. Soc. Exp. Biol. Med. 170: 133-138.

DeHaan, R.L. 1965. Morphogenesis of the vertebrate heart. In Organogenesis (ed. R.L. DeHaan and H. Ursprung), pp. 377-419. Holt, Rinehart and Winston, New York.

DeSimone, J., S.I. Biel, and P. Heller. 1978. Stimulation of fetal hemoglobin synthesis in baboons by hemolysis and hypotoxia. Proc. Natl. Acad. Sci. 75: 2937-2940.

Gardner, D.G., C.F. Deschepper, W.F. Ganong, H. Satoshi, J. Fiddes, J.D. Baxter, and J. Lewicki. 1986. Extra-atrial expres- sion of the gene for atrial natriuretic factor. Proc. Natl. Acad. Sci. 83: 6697-6701.

Hafen, E., M. Levine, R.L. Garber, and W.J. Gehring. 1983. An improved in situ hybridization method for the detection of cellular RNA in Drosophila tissue sections and its application for localizing transcripts of the homeotic Antennapedia gene complex. EMBO J. 2: 617-623.

Hayashi, S., I.C. Gillam, A.D. Delaney, and G.M. Tener. 1978. Acetylation of chromosome squashes of Drosophila melan. ogaster decreases the background in autoradiographs from hybridisation with [ $\left.{ }^{125} \mathrm{I}\right]-$ labeled RNA. I. Histochem. Cytochem 26: 677-679.

Izumo, S., A.M. Lompre, R. Matsuoka, G. Koren, K. Schwartz, B. Nadal-Ginard, and V. Mahdavi. 1987. Myosin heavy chain messenger RNA and protein isoform transitions during cardiac hypertrophy. J. Clin. Invest. 79: 970-977.

Lattion, A.L., J.B. Michel, E. Arnauld, P. Corvol, and F. Soubrier. 1986. Myocardial recruitment during ANF mRNA increase with volume overload in the rat. Am. I. Physiol 251: H890-H896.

Needleman, P., S.P. Adams, B.R. Cole, M.G. Currie, D.M. Geller, M.L. Michener, C.B. Saper, D. Schwartz, and D.G. Standaert. 1985. Atriopeptins as cardiac hormones. Hypertension 7: 469-482.

Nemer, M., J.P. Lavigne, J. Drouin, G. Thibault, M. Gannon, and T. Antakly. 1986. Expression of atrial natriuretic factor gene in heart ventricular tissue. Peptides 7: 1147-1152.

Rebagliati, M.R., D.L. Weeks, R.P. Harvey, and D.A. Melton. 1985. Identification and cloning of localized maternal RNAs from Xenopus eggs. Cell 42: 769-777.

Rudolph, A.M. and M.A. Heymann. 1974. Fetal and neonatal circulation and respiration. Annu. Rev. Physiol. 36: 187207.

Rugh, R. 1968. Chronology of development (8-16 days). In The mouse: Its reproduction and development (ed. R. Rugh), pp. 102-207. Burgess Publ., Minneapolis.

Seidman, C.E., K.D. Bloch, K.A. Klein, J.A. Smith, and J.G. Seidman. 1984. Nucleotide sequences of the human and mouse atrial natriuretic factor genes. Science 226: 12061209.

Snell, G.D. and L.C. Stevens, 1968. Early embryology. In $B i-$ ology of the laboratory mouse (ed. E.L. Green), pp. 205-245. Dover Publ., New York.

Takayanagi, R., T. Imada, and T. Inagami. 1987. Synthesis and presence of atrial natriuretic factor in rat ventricle. Biochem. Biophys. Res. Commun. 142: 483-488.

Thompson, R.P., J.A.V. Simson, and M.G. Currie. 1986. Atriopeptin distribution in the developing rat heart. Anat. Embryol. 175: 227-233.

Wiegand, R.C., M.L. Day, C.P. Rodi, D. Schwartz, and P. Needleman. 1987. Atriopeptin expression in the ventricle. In Clin. Physiol. Series. Atrial hormones and other natriuretic factors (ed. P.J. Mulrow and R. Schrier), pp. 33-39. American Physiological Society, Bethesda, Maryland.

Zeller, R., T. Nyffenegger, and E.M. De Robertis. 1983. Nucleocytoplasmic distribution of snRNPs and stockpiled snRNAbinding proteins during oogenesis and early development in Xenopus laevis. Cell 32: 425-434. 


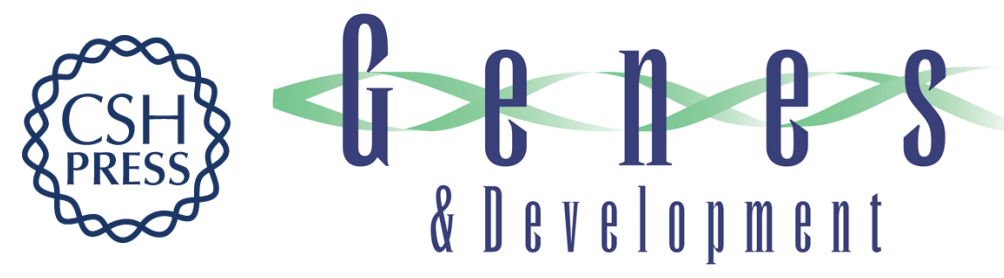

\section{Localized expression of the atrial natriuretic factor gene during cardiac embryogenesis.}

R Zeller, K D Bloch, B S Williams, et al.

Genes Dev. 1987, 1:

Access the most recent version at doi:10.1101/gad.1.7.693

References This article cites 23 articles, 6 of which can be accessed free at: http://genesdev.cshlp.org/content/1/7/693.full.html\#ref-list-1

License

Email Alerting

Receive free email alerts when new articles cite this article - sign up in the box at the top Service right corner of the article or click here.

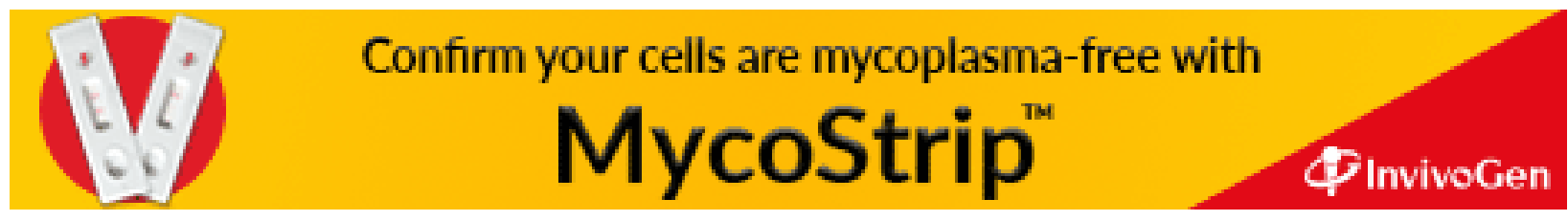

